\title{
GERAKAN DAN REPRESENTASI POLITIK PEREMPUAN DI KOTA TASIKMALAYA
}

\author{
Noneng Masitoh \\ Universitas Siliwangi \\ masitohnoneng@yahoo.com \\ Fitriyani Yuliawati \\ Universitas Siliwangi \\ fitriyaniyuliawati@unsil.ac.id
}

\section{ABSTRAK}

Penelitian ini didasari atas berbagai problem lemahnya peran perempuan yang berdampak pada diskriminasi dalam berbagai aspek kehidupan yang diterima oleh perempuan. Penelitian yang dilakukan di Tasikmalaya ini mencoba untuk menggambarkan gerakan perempuan mulai dari akar rumput dan bagaimana aktor aktor gerakan perempuan merepresentasikan kepentingan perempuan, baik gerakan perempuan yang berasal dari akar rumput maupun yang muncul karena bentukan negara. Metode yang digunakan dalam penelitian ini adalah metode penelitian Kualitatif deskriptif. Paradigma ilmu politik yang digunakan menggunakan teori kritik sosial menggunakan feminisme sebagai pendekatan penelitian. Sedangkan tekhik analisis menggunakan metode interaktif dan data digali secara mendalam lewat purpose methode. Hasil dari penelitian ini adalah: 1. Organisaasi-organisasi perempuan yang ada di Kota Tasikmalaya belum sepenuhnya memiliki 
wadah yang dapat mempersatukan semua golongan, sehingga gerakan masih dilakukan sendiri-sendiri oleh organisasi perempuan masing-masing. 2. Keterwakilan perempuan dalam lembaga politik formal cukup terwakili dengan munculnya tokoh-tokoh yang menjadi representasi perempuan dalam lembaga politik. Secara substantif, keberadaan mereka dalam lembaga-lembaga tersebut belum memberikan implikasi positif yang sangat signifikan. 3. Keberadaaan GOW Kota Tasikmalaya sebagai salah satu wadah bersatunya organisasiorganisasi perempuan di Kota Tasikmalaya belum maksimal dalam mengkoordinir gerakan perempuan di Kota Tasikmalaya.

Kata Kunci : Organisasi Perempuan, Gerakan Perempuan, Representasi Politik Perempuan.

\section{ABSTRACT}

This research is based on the various problems of the role of women which have an impact on discrimination in many aspects of women life. This research which conducted in Tasikmalaya is trying to portray the women's movement from the grassroots and how actors represent women's interests in both women's movement that comes from the grass roots and other movements that affiliated to the state. The method used in this research is descriptive qualitative research methods. The paradigm of political science and the theory of social critique used as a research approaches. While analysis is using interactive methods and data explored in depth through the method purpose. The results of this study are: 1.- Women's organizations in the city of Tasikmalaya have no full power to unite all the groups, so that the movement is still done separately by women's organizations respectively. 2 . The representation of women in formal political institutions are adequately represented by the emergence of figures in politic. Substantively, their presence in these institutions does not provide a significant positive implication. 3. The existence of GOW Tasikmalaya as women's organizations in the city of Tasikmalaya is not maximized in coordinating the women's movement in this city 
Keywords : Women's organization, women's movement, the representation of women in politic

\section{A. Pendahuluan}

Women Movement (gerakan perempuan) bertujuan untuk merepresentasikan kepentingan dan meningkatkan derajat perempuan yang terpuruk karena budaya patriarki yang melekat pada sebagian besar masyarakat Indonesia. Gerakan perempuan mewujud dalam Ormas-ormas dan lembaga swadaya perempuan yang berbasiskan agama, perjuangan identitas, perkumpulan, dan lainnya. Selain lembaga-lembaga politik informal, tidak kalah pentingnya representasi perempuan dalam lembaga politik formal baik sebagai pejabat publik maupun pejabat lembaga pemerintah lainnya.

Kesiapan perempuan untuk maju secara berani mengambil inisiatif dalam segala kebijakan menyangkut hidupnya dan kebaikan masyarakatnya penting diartikulasikan, penguatan hak sipil sebagai bangunan kokoh suatu tatanan negara selayaknya menjadi konsentrasi para aktivis perempuan yang tergabung dalam gerakan perempuan untuk mempercepat gerak perempuan yang tertinggal.

Ada banyak faktor mengapa kaum perempuan sulit untuk memperjuangkan kepentingannya. Dalam lingkup partai, kaum pria memiliki lebih banyak akses untuk menduduki jabatan strategis sementara kaum perempuan dengan peran sosiologis sebagai ibu dan pengurus rumah tangga dianggap tidak selalu "siap pakai". Sifat nature perempuan dianggap kurang mendukung dalam urusan politik dan pemerintahan. Proses reproduksi yang dialami seperti menstruasi, hamil, menyusui, mengurus anak, direduksi sebagai isu nature. Masih adanya pandangan bahwa perempuan berpolitik praktis sebagai sesuatu yang janggal dan diluar kebiasaan, sehingga tidak jarang menimbulkan minder dan menurunkan semangat kaum perempuan. Yang terakhir adalah superioritas laki-laki yang dalam batas tertentu merasa tersaingi atau merasa tidak nyaman jika 
istrinya berperan di luar rumah tangga.

Penelitian ini mengkaji gerakan yang muncul dari akar rumput dan menganalisis peran aktor gerakan perempuan dalam pemberdayaan perempuan di Kota Tasikmalaya. Penelitian ini penting untuk melihat beberapa hal. Pertama, memotret gerakan perempuan dalam mempresentasikan kepentingan perempuan, tidak hanya dijadikan komoditas jargon-jargon kepentingan kampanye semata, tetapi pada upaya membangun dan memberdayakan perempuan agar mandiri dan sejahtera. Kedua, gerakan perempuan dapat menggambarkan bentuk ketidakadilan gender terhadap perempuan seperti diskriminasi dan kekerasan terhadap perempuan di Kota Tasikmalaya. Ketiga, gerakan perempuan mampu memetakan peran melalui pemberdayaan sehingga dapat meningkatkan kesejahteraan perempuan.

Penelitian ini berjenis kualitatif denganpendekatan feminis yang memanfaatkan teknik pengumpulan data yang meliputi wawancara mendalam (Indepth Interview), observasi dan dokumentasi.Pemilihan responden berbentuk snowball sampling hal ini dikarenakan jumlah informan yang berkembang karena kebutuhan akan informasi. Model analisis yang digunakan berbentuk interaktif yang meliputi reduksi data, sajian data, dan penarikan kesimpulan. Validitas data diukur melalui triangulasi sumber (Moleong, 2005 : 36; 165).

\section{B. Pembahasan}

\section{Organisasi Perempuan di Kota Tasikmalaya}

Ketimpangan gender terhadap perempuan berwujud dalam banyak bentuk dan hampir semua aspek kehidupan. Bentuk diskriminasi yang paling sering terjadi adalah pembagian peran perempuan yang hanya sebatas peran domestik yaitu dapur, sumur dan kasur. Pembagian peran yang diskriminatif tersebut telah membuat perempuan termarjinalkan dalam aspek sosial, ekonomi dan politik. Dalam kehidupan sosial perempuan masih dipandang sebagai 
makhluk nomor dua di bawah laki-laki dan yang berdampak pada aspek ekonomi ,menyebabkan perempuan lemah secara ekonomi dan banyak tergantung pada laki-laki. Dunia kerja memberikan ruang terhadap perempuan haya saja dengan beban kerja yang sama atau lebih berat dari laki-laki seringkali mendapatkan upah yang lebih kecil dari laki-laki. Sementara dalam politik, keterlibatan perempuan masih dipandang sebelah mata, bahkan oleh perempuan yang lainya, hal ini terjadi karena stereotipe perempuan dianggap tidak akan mampu masuk dalam dunia politik.

Gerakan organisasi perempuan di kota Tasikmalaya telah berperan dan dipersiapkan untuk menjadi para pengurus awal organisasi. Salah satu organisasi yang ada di Tasikmalaya adalah Aisyiyah. Penguatan gerakan perempuan sejalan dengan visi organisasi Aisyiyah. Visi Aisyiyah adalah sebagai berikut:

1. Berkembangnya Islam berkemajuan dalam kehidupan masyarakat khususnya lingkungan umat Islam dimana Aisyiyah berada.

2. Berkembanganya gerakan pencerahan yang membaawa proses pembebasan, pemberdayaan, dan pemajuan dalam kehidupan keumatan dan kebangsaan.

3. Berkembangnya perempuan berkemajuan di lingkungan umat Islam dan bangsa Indonesia maupun ranah global sebagai insan pelaku perubahan menuju peradaban utama yang cerah dan mencerahkan.

Islam yang berkemajuan menurut Aisyiyah dalam visi yang pertama adalah jalan Islam yang membebaskan, memberdayakan dan memajukan kehidupan dari segala bentuk keterbelakangan, ketertindasan, kejumudan dan ketidakadilan hidup manusia. Sementara dalam visi yang kedua, gerakan pencerahan (tanwir) merupakan praksis Islam yang berkemajuan untuk membebaskan, memberdayakan, dan memajukan kehidupan. Gerakan pencerahan dihadirkan untuk memberikan jawaban atas problem-problem kemanusiaan berupa kemiskinan, kebodohan, ketertinggalan, 
dan persoalan-persoalan lainnya yang bercorak struktural dan kultural. Gerakan pencerahan menampilkan Islam untuk menjawab masalah kekeringan rohani, krisis moral, kekerasan, terorisme, konflik, korupsi, kerusakan ekologis dan bentuk-bentuk kejahatan kemanusiaan. Selain itu, gerakan pencerahan berkomitmen untuk mengembangkan relasi sosial yang berkeadilan tanpa diskriminasi, memuliakan martabat manusia laki-laki dan perempuan, menjunjung tinggi toleransi dan kemajemukan, dan membangun pranata sosial yang utama.Visi ketiga Aisyiyah yaitu memajukan perempuan. Aisyiyah sebagai organisasi perempuan Muhamadiyah, dihadirkan untuk mewujudkan kehidupan perempuan berkemajuan dalam seluruh aspek kehidupan.

Selain Aisyiyah, Organisasi Perempuan yang cukup besar di Kota Tasikmalaya adalah Muslimat Nahdhatul Ulama (Muslimat NU) yang diketuai oleh $\mathrm{Hj}$. Ai Muhamad. Penguatan gerakan perempuan tercermin dalam visi dam misi Muslimat NU yang bertujuan untuk terwujudnya masyarakat sejahtera yang dijiwai ajaran Islam Ahlusunnah wal jamaah dalam Negara Kesatuan Republik Indonesia yang berkemakmuran dan berkeadilan yang diridloi Allah SWT.

Secara historis, visi kemajuan perempuan tercermin dalam sejarah munculnya muslimat NU. Dalam kongres NU XIII untuk pertama kalinya tampil seorang muslimat NU di atas podium, berbicara tentang perlunya wanita NU mendapatkan hak yang sama dengan kaum lelaki dalam menerima didikan agama melalui organisasi NU. Verslag kongres NU XIII mencatat : "Pada hari Rebo ddo: 15 Juni'38 sekira poekoel 3 habis dhohor telah dilangsoengkan openbare vergadering (dari kongres) bagi kaoem iboe, ...Tentang tempat kaoem iboe dan kaoem bapak jang memegang pimpinan dan wakil-wakil pemerintah adalah terpisah satoe dengan lainnja dengan batas kain poetih." Sejak kongres NU di Menes, wanita telah secara resmi diterima menjadi anggota NU meskipun sifat keanggotannya hanya sebagai pendengar dan pengikut saja, tanpa diperbolehkan 
menduduki kursi kepengurusan. Hal seperti itu terus berlangsung hingga Kongres NU XV di Surabaya tahun 1940. Dalam kongres tersebut terjadi pembahasan yang cukup sengit tentang usulan Muslimat yang hendak menjadi bagian tersendiri, mempunyai kepengurusan tersendiri dalam tubuh NU

Organisasi perempuan lain yang cukup aktif dalam gerakan perempuan di Kota Tasikmalaya adalah Wanita Katolik Republik Indonesia Cabang Kota Tasikmalaya, Organisasi yang bersifat sosial aktif, mandiri, memiliki kekuatan moral dan kemampuan yang handal dalam menjalankan karya-karya pengabdian untuk mewujudkan kesejahteraan bersama serta menegakkan harkat dan martabat manusia. sebagai salah satu golongan minoritas di Kota Tasikmalaya hal ini tidak menyurutkan para anggota Wanita Khatolik RI untuk menjalankan Visi dan Misi organisasinya. Wanita Katholik RI di Kota Tasikmalaya sering melakukan kegiatan-kegiatan yang bersifat pemberdayaan perempuan (Wawancara Dewi Untari selaku Ketua Wanita Katholik RI)

Penguatan perempuan sejalan dengan visi dan misi Wanita Katolik RI sebagai organisasi yang bersifat sosial aktif, mandiri, memiliki kekuatan moral dan kemampuan yang handal dalam menjalankan karya-karya pengabdian untuk mewujudkan kesejahteraan bersama serta menegakkan harkat dan martabat manusia. Pemberdayaan perempuan tercermin dalam misi Wanita Katolik RI dalam

a. Mengembangkan kemampuan serta memberdayakan seluruh jajaran Wanita Katolik RI, guna meningkatkan kualitas pengabdian dalam masyarakat.

b. Menghimpun aspirasi dan mengaktualisasikan potensi Wanita Katolik RI agar karya pengabdian terwujud secara optimal dan berkesinambungan,

c. Memperjuangkan kesetaraan dan keadilan gender dalam seluruh dimensi kehidupan 
d. Mengupayakan lingkungan hidup yang seimbang.

Organisasi perempuan berikutnya adalah Persatuan Islam Istri yang disingkat dengan Persistri. Organisasi ini tidak tegabung dalam Gabungan Organisasi Wanita Kota Tasikmalaya. Isu penguatan dan pemberdayaan perempuan sejalan dengan visi dan misi Persistri sebagai berikut. Visinya adalah terciptanya masyarakat perempuan yang berpegang teguh pada syariat islam berlandaskan Al-Qur'an dan Assunah. Sementara misi bertujuan untuk mendidik muslimah hidup berjama'ah, berimamah, berimarah, tunduk dan taat kepada nizham jam'iyyah yang sejalan dengan Al-Qur'an dan Assunah.Persistri tidak mengikuti Gabungan Orgnisasi Wanita Kota Tasikmalaya (wawancara Ketua Persistri Hj. Ai Kurniasih). Pilihan organisasi perempuan ini mempelihatkan gerakan perempuan di Kota Tasikmalaya masih belum mempunyai arah dan tujuan yang merangkul semua golongan, bahkan penolakan datang dari bagian golongan yang cukup berpengaruh di Kota Tasikmalaya.

\section{Representasi Politik Organisasi Perempuan di Kota Tasikmalaya}

Berbicara representasi politik dalam kajian ilmu politik sangatlah menarik, dikarenakan terkait erat dengan keinginan untuk merepresentasikan kepentingan kelompok tertentu dalam masyarakat. Representasi politik biasanya berkonotasi dengan lembaga politik misalnya parlemen, tempat berbagai wakil rakyat dalam penyelenggaraan pemerintahan. Terdapat dua model perwakilan dalam kajian Ilmu politik yang sudah lazim yakni pertama, perwakilan dan mekanisme formal. Model ini lazim ditemukan dalam pemerintahan negara-negara di dunia saat ini lewat parlemen atau sejenis DPR di Indonesia. Mekanismenya pun di setiap negara sudah sangat rigid dibuat dalam bentuk perundangundangan dan setiap negara memiliki variasi tertentu dalam model mekanisme perwakilan formalnya. Kedua, perwakilan tidak formal dan tidak ada mekanisme yang secara jelas tertulis. Model kedua ini biasanya mendasarkan pada konsensus tertentu dan dalam 
pelaksanaannya sangat dinamis, tergantung kondisi sosial-politik dan budaya (social-contruction) sebuah negara.

Berdasarkan pemahaman di atas, persoalan representasi bukanlah persoalan yang sederhana, karena tentu banyak pertanyaan kemudian yang terkait dengan kepentingan apa yang direpresentasikan, siapa yang merepsentasikan dan siapa yang direpresentasikan. Dalam konteks politik negara-bangsa (nationstate) membicarakan tiga unsur dalam representasi di atas, karena akan terkait dengan kontestasi kepentingan, pergulatan politik antara yang diwakili dengan yang mewakili dan seterusnya. Kajian penelitian membatasi untuk membahas tentang keterwakilan perempuan, baik secara kuantitas pelakunya maupun secara substansi lewat keterwakilan isu, gagasan, perubahan cara fikir, dalam kerangka untuk memperjuangkan aspirasi, problematika secara utuh tentang keperempuanan dalam lembaga-lembaga politik, baik formal maupun informal di Kota Tasikmalaya.

Representasi perempuan dalam lembaga politik formal seperti pejabat publik dan lembaga pemerintah lainnya meskipun terdapat affirmati action seperti melalui upaya kuota $30 \%$ perempuan di kepengurusan Parpol, dan lembaga politik lainnya tetapi di Tasikmalaya kondisi tersebut masih belum terasa sangat signifikan. Selain secara kuantitas perempuan masih sangat terbatas dalam lembaga legislatif, juga posisinya di Kota Tasikmalaya masih dianggap hanya sebagai "penghias".

Budaya politik masyarakat Tasikmalaya memang belum percaya penuh kepada kepemimpinan perempuan. Walaupun keinginan dan kemampuan perempuan dalam politik sudah terpenuhi, jika tidak adanya dukungan dari masyarakat untuk memilihnya pasti tidak akan berhasil. Dukungan dari keluarga, masyarakat dan partai politik bagi perempuan sangat berpengaruh. Apalagi banyak masyarakat memandang sebelah mata pada kaum perempuan, perempuan selalu dinomorduakan baik dari segi kemampuan ataupun dari segi posisi. Hal ini, menjadi tugas gerakan perempuan di Kota Tasikmalaya agar 
lebih berperan aktif.

Banyak para caleg perempuan berpendapat bahwa tidak ada kendala dalam pencalonan, partai politik mereka sangat memudahkan dan mendukung. Tapi ada juga salah satu caleg perempuan yang mempunyai kendala dari keluarga dan masyarakat, karena berprofesi sebagai pendakwah jadi banyak masyarakat kurang setuju mencalonkan diri jadi anggota dewan katanya lebih baik berdakwah saja meski mendapatkan dukungan dari partai politik.

Keterwakilan menyangkut dua hal penting, yakni : pertama, keterwakilan secara kuantitas dan kedua, keterwakilan secara substantif. Keterwakilan secara kuantitas dimaknai bahwa ada pihak dari perempuan yang secara langsung terlibat dalam lembaga politik dan menjadi bagian dalam pembuatan kebijakaan. Sedangkan secara substantif, bagaimana isu-isu permpuan dapat mengemuka, bahkan menjadi isu utama yang dibicarakan dalam setiap pengambilan kebijakan, baik itu disuarakan oleh perempuan itu sendiri, mapun laki-laki yang sensitive terhadap isu-isu kesetaraan gender.

Berdasarkan jumlah, anggota DPRD Perempuan yang ada di Kota Tasikmalaya pada tahun 2014-2015 berjumlah lima orang. Keterwakilan secara substansi diukur melalui fungsi yang diemban oleh setiap anggota parlemen. Terdapat tiga fungsi dari parlemen yaitu fungsi legislasi, pengawasan dan anggaran. Fungsi legislasi yang dituntut untuk bersama-sama dengan eksekutif membentuk produk hukum yang sesuai dan aspiratif masyarakat Kota Tasikmalaya. Dalam fungsi pengawasan berusaha melaksanakan pengawasan terhadap pelaksana (eksekutif) sehingga kontrol terhadap eksekutif dapat berjalan dengan baik bebas dari KKN. Fungsi anggaran memberi amanat anggota dewan untuk menyusun anggaran bersama-sama dengan eksekutif secara efisien dan efektif tanpa mengindahkan kepentingan masyarakat umum sehingga asas pemborosan dapat ditekan serendah mungkin.

Majunya lima anggota dewan perempuan daerah Kota 
Tasikamalaya dalam dunia politik sudah dirintis dari munculnya seorang anggota organisasi perempuan menjadi anggota dewan. Kesadaran ini dilatarbelakangi pandangan bahwa perempuan mampu ambil bagian berkecimpung dalam bidang politik sebagai bagian darri ruang publik dengan tetap menyeimbangkan peran dalam ruang domestik. Para anggota dewan perempuan tersebut dapat eksis membina karir politiknya sebagai strategi keterlibatan perempuan dalam membuat keputusan politik. Perempuan memiliki kebutuhan- kebutuhan khusus yang hanya dapat dipahami paling baik oleh perempuan sendiri. Kebutuhan - kebutuhan ini meliputi:

a) Isu-isu kesehatan reproduksi, seperti cara KB yang aman.

b) Isu-isu kesejahteraan keluarga, seperti harga sembilan bahan pokok yang terjangkau, masalah kesehatan dan pendidikan anak.

c). Isu-isu kepedulian terhadap anak, kelompok usia lanjut dan tuna daksa ( cacat tidak bekerja)

d). Isu-isu kekerasan seksual.

Keterlibatan perempuan sebagai pembuat keputusan politik dapat memberikan jaminan dan perlindungan perempuan dari diskriminasi yang selama ini terjadi dalam masyarakat, antara lain diskriminasi di tempat kerja yang menganggap pekerja laki-laki lebih tinggi nilainya daripada perempuan. Misalnya penetapan upah yang berbeda antara laki-laki dan perempuan untuk beban kerja yang sama. Diskriminasi di hadapan hukum yang merugikan posisi perempuan misalnya, kasus perceraian.

Masyarakat Kota Tasikmalaya sebagaimana masyarakat di Indonesia pada umumnya dikuasai oleh nalar dan budaya patriarki. Label dan cap yang diberikan pada sosok perempuan sangat kental sebagai sosok yang lemah, tidak bermanfaat dan terbelenggu ketergantungan telah didoktrin secara turun-temurun sebagai kebiasaan masyarakat Sunda, khususnya Kota Tasikmalaya. Dalam mayarakat Tasikmalaya, perempuan diposisikan pada kelas dua yang tempatnya di ruang privat saja dengan segala kesibukan yang 
tiada henti dan tidak berbekas. Perempuan dianggap tidak pantas bergelut dengan dunia politik yang penuh dengan kekerasan dan kekasaran permainan kekuasaan. Perempuan dinilai tidak mampu memimpin dan membuat kebijakan karena patron membentuk perempuan sangat tendensius mengutamakan perasaan sehingga jauh dari sikap rasionalitas, persepsi negatif tersebut dilekatkan pada perempuan sendiri telah terstruktur sedemikian rupa dibenak kaum perempuan dan kaum laki-laki. Padahal perempuan memiliki hak dan kewajiban yang sama sebagai warga negara dalam mengatur kesejahteraan manusia, begitu pula dalam hal mengaktualisasikan perannya. Namun realitas yang terjadi perempuan masih terkungkung oleh tidak adanya ruang kesempatan memadai mengaktualisasikan perannya.

Beberapa faktor penyebab ketertinggalan perempuan dalam kepengurusan partai politik di Kota Tasikmalaya : pertama, dalam karir politik dalam partai, kaum pria lebih banyak memiliki pilihan untuk menjadi SDM yang bermutu, daripada perempuan. Kultur sosial masyarakat Kota Tasikmalaya yang masih patriarki dikuatkan dengan kultur pesantren yang lebih mengangkat posisi laki-laki. Kedua, kaum perempuan dengan perannya sebagai ibu dan pengurus rumah tangga, dianggap tidak selalu "siap pakai" dalam mengurusi organisasi, apalagi lembaga-lembaga politik, seperti LSM yang concern dengan peran-peran Negara, legislatif, Parpol dan lembaga politik lainnya. Adanya orientasi pemikiran yang berbeda antara laki-laki dan perempuan, perempuan pola pikirnya lebih internaleksklusif, sedangkan laki-laki eksternal-inklusif. Ketiga, sifat nature dari perempuan dianggap kurang mendukung dalam urusan politik dan pemerintahan seperti hamil, menyusui, mengurus anak, menstruasi sehingga harus pikir-pikir dahulu bagi perempuan masuk dalam institusi politik yang "serba keras". Keempat, direduksinya isu nurture sebagai isu nature, artinya masih adanya pandangan bahwa perempuan berpolitik praktis sebagai sesuatu yang janggal dan diluar kebiasaan, sehingga tidak jarang menimbulkan minder 
dan menurunkan semangat kaum perempuan. Kelima, superioritas laki-laki yang dalam dataran tertentu akan merasa tidak nyaman jika istrinya berperan di luar rumah tangga, atau dalam hal tertentu merasa tersaingi.

Sementara tentang out-put legislasi yang diukur dari adanya peraturan yang berpihak kepada kaum perempuan di segala bidang dan aktivitas. Isu gender menjadi sorotan penting dalam berbagai pembahasan undang-undang di DPR, terutama tentang kontroversi perlunya penanganan khusus untuk perempuan. Bagi yang kontra terhadap adanya affirmative action terhadap perempuan, persoalan ketimpangan gender perlu ditangani dengan merubah cara pandang, bukan dengan pengistimewaan. Cara pandang tersebut bisa dirubah dengan pendidikan politik, kampanye-kampanye kesetaraan gender dan lainnya. UU No.2 tahun 2008 dipandang cukup memberikan peluang bagi perempuan dalam politik praktis di Kota Tasikmalaya. Regulasi ini menimbulkan problematika baru karena SDM perempuan dalam tingkat pendidikan dan manajerial kaum perempuan tidak seimbang dengan tuntutan pemenuhan kuota. Problematika ini memberikan pekerjaan runah bagi pemerintah dan masyarakat Kota Tasikmalaya. pertama, aturan tersebut merupakan tantangan bagi parpol di Kota Tasikmalaya untuk memajukan kaum perempuan. Dengan "paksaan” aturan yang ketat sebagai syarat agar lolos verifikasi, parpol di Kota Tasikmalaya harus mampu melakukan pendidikan politik, mencerdaskan dan memajukan kaum perempuan, terutama konstituennya. Jika kader-kader partai dari kalangan perempuan berkemampuan lebih rendah daripada kaum pria, sementara perempuan adalah asset dalam organik partai, maka tugas partai politik adalah menjadikan perempuan sebagai sumber daya elit partai. Perempuan harus diproses supaya siap dalam lingkaran elit, memiliki pribadi yang mandiri, percaya diri, memiliki jati diri, di samping keterampilannya dalam bidang politik dan mampu membagi perannya secara bijak sebagai elit partai dan sebagai pengurus rumah tangga. 
Kedua, aturan tersebut merupakan upaya pemberian kesempatan luas bagi kaum perempuan untuk berkiprah dalam pentas perpolitikan, baik lokal maupun nasional. Kesempatan yang "diwajibkan" bagi setiap partai untuk memberikan kesempatan seluas-luasnya bagi perempuan untuk aktif dalam institusi politik. Namun, yang kemudian harus menjadi catatan adalah kaum perempuan agar tidak merasa puas dengan pemberian kesempatan tersebut atau menjadi anggota legislatif tanpa mau belajar memperbaiki kualitas sumber daya manusianya. Kaum perempuan hendaknya menyadari bahwa sistem kuota juga harus dipahami sebagai media pencerdasan sense of social kaum perempuan lewat kran institusi politik praktis. Dengan demikian, perempuan memiliki kesempatan sekaligus tantangan bagi pemberian kuota. Satu hal penting yang secepatnya harus dilakukan perempuan Indonesia saat ini adalah "bersekolah". "Bersekolah" sambil berkarya, berperan menjadi aktor politik dalam partai dan parlemen. "Bersekolah" dengan pelajaran memasuki persaingan (competitive prosess) yang ekstra.

Peratuan baru tersebut juga bisa dikatakan sebagai upaya "feminisasi politik", maksudnya proses bagaimana perempuan mendapat peluang yang luas dalam berperan dalam institusi elit politik dan tentunya mewakili aspirasi kaum perempuan khususnya dan umumnya ketidakadilan yang terjadi. Esensi peraturan tersebut memiliki tiga hal penting sebagai keterwakilan perempuan dalam politik yakni : aspek pendirian dan pembentukan partai, kepenguruan partai politik dan pendidikan politik perempuan. Terlihat eksplisit dari tiga aspek tersebut memaknakan terbukanya peluang luas bagi kaum perempuan untuk terlibat dalam proses politik. Keterlibatan tidak hanya berupa inisiatif dari perempuan, tetapi juga tindakan bijak yang proaktif bagi setiap partai politik mencari kader perempuan untuk duduk dalam struktur parpol, mulai dari sejak pendirian, kepengurusan, hingga proses penentuan calon legislatif.

Demokrasi Indonesia selama ini hanya mengedepankan aspek 
prosedural dan bersifat keterwakilan umum masyarakat namun belum menekankan pada akomodasi terhadap keterwakilan kepentingan dan golongan-golongan minoritas. Inilah yang menyebabkan demokrasi di Indonesia belum berhasil, karena belum mampu mewakili individu maupun kelompok yang memiliki perbedaan karakter sosial. Undang-undang baru tersebut menjadi babak baru mulai diakomodasinya entitas individu maupun kelompok dalam masyarakat, terutama perempuan.

\section{Simpulan}

Berdasar pada pemaparan di atas, diperoleh kesimpulan sebagai berikut. Pertama, Organisaasi-organisasi perempuan yang ada di Kota Tasikmalaya belum sepenuhnya memiliki wadah yang dapat mempersatukan semua golongan, sehingga gerakan masih dilakukan sendiri-sendiri oleh organisasi perempuan masingmasing. Secara kuantitas keterwakilan perempuan dalam lembaga politik formal cukup terwakili dengan munculnya tokoh-tokoh yang menjadi representasi perempuan dalam lembag politik vital seperti DPRD, lembaga pemerintahan, beberapa menjadi pemimpin partai politik, baik ketua maupun top leader lainnya. Kedua, secara substantif, keberadaan mereka dalam lembaga-lembaga tersebut belum memberikan implikasi positif yang sangat signifikan. Ketiga, keberadaaan GOW Kota Tasikmalaya yang memiliki akses langsung dengan pemerintah sebagai wadah bersatunya organisasiorganisasi perempuan di Kota Tasikmalaya belum maksimal dalam mengkoordinir gerakan perempuan di Kota Tasikmalaya dan mampu menggerakkan organisasi-organisasi perempuan di Kota Tasikmlaya untuk bagkit dan mensejahterakan perempuan. 


\section{DAFTAR PUSTAKA}

Anugerah, Astrid. (2009). Keterwakilan Perempuan dalam Politik, Penerbit Pancuran Alam, Cet II, Jakarta.

Andrew Heywood. (2002).Politics : Second Edition, Palgrave, NY.

Fakih, Mansour. (2010). Analisis Gender dan Transformasi Sosial, Pustaka Pelajar, Yogyakarta

Fauzia, Amelia, dkk. (2004). Tentang Perempuan Islam: Wacana dan Gerakan, Gramedia Pustaka Utama dan PPIM UIN, Jakarta.

Masitoh, Noneng \& Rosidah, Euis. (2010). Pengaruh Gaya Kepemimpinan Birokrasi, Budaya dan Pendidkan Terhadap Keadilan dan Kesetaraan Gender Di pemerintahan Kota Tasikmalaya.Hasil Penelitian Dosen Pemula Universitas Siliwangi.

Miles, Mathew dan A. Huberman. (1992). Analisa Data Kualitatif. UI Press. Jakarta.

Moleong, Lexy J. (2000). Metodologi Penelitian Kualitatif. PT Remaja Rosdakarya, Bandung.

Sen, Amartya. (1999). Development as Freedom, Oxford University Press, United States Of America.

Sutopo, Heribertus. (1996). Metodologi Penelitian Kualitatif, UNS, Surakarta.

Sydie, Rosalind. (1987). Natural Women, Culture Men A Feminist Perspective on Sociological Theory, Ontario Methanen Publications

Wolf, Naomi. ( 1993). Fire With Fire: The New Female Power and How to Use It, Oxford University

Agung, Subhan, Yuliawati, Fitriyani. (2013). Representasi Perempuan dalam Lembaga Politik di Kota Tasikmalaya, Hasil Penelitian Dosen Pemula, Universitas Siliwangi, Tasikmalaya.

Yuliawati, Fitriyani, Widiastuti, Wiwi. (2014). Gender dan Politik: 
Gerakan Dan Representasi Politik Perempuan Di Kota Tasikmalaya Analisis Kemenangan Ade UU Sukaesih dalam Pilkada Banjar 2013, Laporan Penelitian Universitas Siliwangi, Tasikmalaya. 
Halaman ini bukan sengaja untuk dikosongkan 